DOI 10.15290/cnisk.2019.01.06.05

PROF. DR HAB. JOLANTA CHWASTYK-KOWALCZYK

https://orcid.org/0000-0002-3463-6432

Uniwersytet Jana Kochanowskiego w Kielcach

\title{
Agitacja obywatelska przed- i powyborcza 1928 roku na łamach „Kobiety Współczesnej”
}

\section{Streszczenie}

„Kobieta Współczesna. Ilustrowany Tygodnik Społeczno-Literacki” to czasopismo wychodzace w Warszawie w latach 1927-1934, edytowane przez Emilię Grocholska, skierowane do kobiecej inteligencji. W okresie ukazywania się redakcja prowadziła nieustająca agitację na rzecz równouprawnienia kobiet, uświadomienia politycznego i apelowała do czytelniczek o czynne włączenie się Polek w życie polityczne kraju. Żądała wzięcia udziału w wyborach do sejmu, senatu oraz $\mathrm{w}$ wyborach samorzadowych. Informowała o życiu politycznym kobiet na świecie.

Słowa kluczowe: „Kobieta Współczesna”, agitacja obywatelska kobiet, życie polityczne, wybory parlamentarne i lokalne, Polska 1918-1939, kobiety posłanki, senatorki

\section{THE CIVIC AGITATION BEFORE AND AFTER THE ELECTIONS OF 1928 IN THE „KOBIETA WSPÓECZESNA” [CONTEMPORARY WOMAN] WEEKLY}

\begin{abstract}
"Kobieta Współczesna. Ilustrowany Tygodnik Społeczno-Literacki” [Contemporary Woman. Illustrated Social and Literary Weekly] was a magazine published in Warsaw in the years 1927-1934, edited by Emilia Grochol-
\end{abstract}


ska, addressed to women's intelligentsia. During its publication period, the editors carried out continuous agitation for women's equality, political awareness and appealed to its Polish readers for their active participation in the political life of their country. The magazine demanded participation in parliamentary elections to the upper and lower house, and in local elections. It informed about the political life of women in the world.

Keywords: „Kobieta Wspótczesna”, women's civic agitation, political life, parliamentary and local elections, Poland 1918-1939, female members of parliament and senators

\section{Wstęp}

W okresie dwudziestolecia międzywojennego wiele czasopism skierowanych do kobiet i redagowanych przez kobiety w ramach walki o równouprawnienie prowadziło agitację na rzecz ich uświadomienia politycznego i uobywatelnienia, co miało się przekładać na czynny udział w życiu politycznym kraju. Wśród periodyków organizacji politycznych, wyróżniających się intensywnością pracy agitacyjnej należy wymienić: „Robotnicę" Marii Turzymy - organ PPS, ukazujący się w Warszawie ${ }^{1}$, „Głos Kobiet”" na Ślassku Cieszyńskim, a od 1907 r. w Warszawie, „Na Posterunku" 3 - organ Ligi Kobiet, efemeryda grupy kobiet postępowych, założone w okresie walki wyborczej w 1919 r. „Kobieta w Sejmie”, pisma Narodowej Organizacji Kobiet: „Gazeta dla Kobiet” (1922-1931), lwowski „Ruch Kobiecy” i „Hasło Polski” z Bielska Cieszyńskiego; od 1928 r. w ramach BBWR, organ Związku Pracy Obywatelskiej Kobiet - „Praca Obywatelska”4 i „Prosta Droga” (dla wsi) ${ }^{5}$. Można wymienić także efemerydę wydawnicza, edytowany w Warszawie w latach 1935-1936 „Tygodnik

\footnotetext{
Wydawana od 1904 r. jako dodatek do „Nowego Słowa”; w latach 1905-1907 była organem Zwiazku Kobiet, a od 1907 r. dodatkiem do socjalistycznego „Naprzodu”.

2 Zob. Aneta Dawidowicz, „Problematyka polityki i polityków na łamach "Głosu Kobiet”, czasopisma dla kobiet wydawanego w latach 1908-1939”, w: Małgorzata Dajnowicz, Adam Miodowski (red.), Polityka i politycy $w$ prasie XX i XXI wieku. Polityka $w$ prasie kobiecej, (Białystok : Wydawnictwo Uniwersytetu w Białymstoku, 2019), 57-71.

3 Zob. Ewa Maj, „Kobieta wobec polityki: strategie tożsamościowe w publicystyce tygodnika "Na Posterunku" (1917-1919)", w: Ibidem, 43-56.

4 Zob. Joanna Dufrat, „Polityka na łamach "Pracy Obywatelskiej» (1928-1939), organu prasowego sanacyjnego Zwiazku Pracy Obywatelskiej Kobiet”, w: Ibidem, 117-129.

5 Por. Zofia Zaleska, Czasopisma kobiece w Polsce. (Materiały do historii czasopism). Rok 1818-1937, (Warszawa : Wyższa Szkoła Dziennikarska, 1938), 115-129.
} 


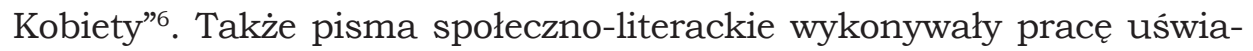
damiająca politycznie swoje odbiorczynie. Wśród nich w okresie 1918-

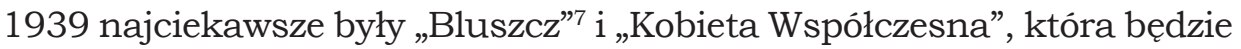
przedmiotem dalszych rozważań. Przy opracowaniu artykułu wykorzystano jakościową analizę zawartości prasy materiałów opublikowanych w „Kobiecie Współczesnej” w latach 1928-1931.

\section{Rozwinięcie}

„Kobieta Współczesna. Ilustrowany Tygodnik Społeczno-Literacki" to czasopismo ukazujące się w Warszawie w latach 1927-1934, edytowane przez Emilię Grocholska, skierowane do kobiecej inteligencji. Redaktorkami naczelnymi były kolejno: Wanda Pełczyńska (1927-1932), Emilia Grocholska i Komitet Redakcyjny w składzie: Hanna Boguszewska, Czesława Wojeńska, Irena Jabłowska (1931-1934) . Znajdziemy w nim artykuły, szkice, reportaże ze wszystkich dziedzin życia społecznego, zawodowego, kulturalnego i przede wszystkim politycznego. Stałymi współpracowniczkami były działaczki $z$ obozu postępowego o radykalnych poglądach głoszacych równouprawnienie kobiet i promujących ich dokonania w życiu społecznym, politycznym, naukowym i artystycznym odrodzonego państwa polskiego ${ }^{9}$. W redakcji „Kobiety Współczesnej” mieściła się siedziba Zarządu Głównego Polskiego Stowarzyszenia Kobiet z Wyższym Wykształceniem ${ }^{10}$.

6 Zob. Maria Bauchrowicz-Tocka, „Zakonspirowane mężatki”, czyli o ograniczeniach obyczajowych i prawnych wobec pracujących kobiet na łamach "Tygodnika Kobiety", w: Małgorzata Dajnowicz, Adam Miodowski (red.), Polityka i politycy w prasie XX $i$ XXI wieku, 103-116.

7 Zob. Jolanta Chwastyk-Kowalczyk, „Próby uobywatelnienia kobiet w okresie dwudziestolecia międzywojennego na łamach "Bluszczu»", w: Małgorzata Dajnowicz, Adam Miodowski (red.), Ibidem, 75-102.

8 Por. Zofia Zaleska, Czasopisma kobiece $w$ Polsce, 150.

9 Dobrochna Kałwa, „Model kobiety aktywnej na tle sporów światopoglądowych. Ruch feministyczny w dwudziestoleciu międzywojennym”, w: Anna Żarnowska, Andrzej Szwarc (red.), Równe prawa i nierówne szanse: kobiety $w$ Polsce międzywojennej, (Warszawa : DiG, 2000), 135-153; Magda Gawin, „Planowanie rodziny - hasła i rzeczywistość”, w: Ibidem, 225.

10 Maria Wierzbicka, „Polskie Stowarzyszenie Kobiet z Wyższym Wykształceniem”, w: Agnieszka Janiak-Jasińska, Katarzyna Sierakowska, Andrzej Szwarc (red.), Działaczki społeczne, feministki, obywatelki. Samoorganizowanie sie kobiet na ziemiach polskich po 1918 roku (na tle porównawczym), t. 2, (Warszawa : B5, 2009), 153-175; Dobrochna Kałwa, „Model kobiety aktywnej”, 148-149; Polskie Kobiece Stowarzyszenia i Zwiazki 
Było to jedno $z$ nielicznych czasopism postępowych, które zdecydowało się zainicjować na swoich łamach debaty na temat świadomego macierzyństwa, oddając eklektycznie głos kobietom oraz feministycznym i konserwatywnym organizacjom kobiecym. Całe cykle artykułów i reportaży poświęcono zagadnieniom ochrony praw dziecka, praw kobiet w pracy, kwestiom zawodowego kształcenia kobiet, współczesnej rodziny.

Do autorów stale współpracujacych $z$ pismem należeli m.in.: Karolina Bielańska, Zdzisław Broncel, Helena Ceysingerówna, Michał Choromański, Maria Czapska, Julia Dickstein-Wieleżyńska, Krystyna Heymanówna, Maria Karczewska, Halina Krahelska, Stanisława Kuszelewska-Rayska, dr Helena Leleszówna, Teodora Męczkowska, Kazimiera Muszałówna, Janina Osińska, Halina Radlińska, Anna Paradowska-Szelagowska, dr H. Silberowa, Hanna Skarbek, Anna Szelagowska, adw. Grażyna Szmurowa, Cecylia Walewska, dr Halina Więckowska, Czesława Wojeńska. Swoje utwory drukowały: Helena Boguszewska, Maria Dabrowska, Kazimiera Iłłakowiczówna, Maria Kuncewiczowa, Wanda Melcer, Zofia Nałkowska, Maria Pawlikowska i inne. Zaznaczyć należy, że większość $z$ tych nazwisk pojawiała się także w „Bluszczu”.

W 1931 r. w „Kobiecie Współczesnej” ukazał się artykuł zatytułowany Do czego dażymy ${ }^{11}$, program ideowy kobiety nowoczesnej autorstwa Teodory Męczkowskiej ${ }^{12}$. Był to referat wygłoszony przez nią na Zjeździe Przewodniczących Kół Kobiet z Wyższym Wykształceniem w styczniu tego roku w Krakowie. Podjęto w nim kwestie pracy zawodowej i udziału w życiu społeczno-politycznym. Autorka napisała wprost, że

w gruncie rzeczy mało się w położeniu kobiet zmieniło, że doniosłe artykuły Konstytucji § 96 i inne, głoszace jej pełne równouprawnienie sa papierowa fikcja. Bo gdzież te wszystkie urzędy, do których są kobiety dopuszczane? Gdzie stanowiska, które zajmuja? Niższe stopnie służbowe i najniższe stoja przed kobietą otworem, ale od wyższych sa starannie odsuwane. ... Równouprawnienia nie ma. ... Taki stan rzeczy musi być przez nas - kobiety $z$ wyższym wykształceniem uważany za nienormalny, ... na który my się zgodzić nie możemy, nie przesta-

\footnotetext{
Wspótpracy Międzynarodowej Kobiet, oprac. Jan Bełcikowski, (Warszawa : Towarzystwo Wydawnicze „Polska Zjednoczona”, 1939), 103-112.

11 Teodora Męczkowska, „Do czego dążymy?”, Kobieta Wspótczesna, nr 39, 1931, 1-3.

12 Hasło: „Męczkowska Teodora” oprac. Halina Więckowska, w: Polski Słownik Biograficzny, t. 20, (Wrocław-Warszawa-Kraków-Gdańsk: Wydawnictwo Polskiej Akademii Nauk, 1975), 503-504.
} 
niemy dopóki nie przekształcimy istniejących, a tradycją uświęconych obyczajów $^{13}$.

Męczkowska uważała to za cel, który powinien łączyć wszystkie kobiety w Polsce i we wszystkich krajach świata. W dobie przemian współczesnej jej rzeczywistości domagała się demokracji w dopuszczeniu kobiet do życia społecznego, zawodowego, jak również politycznego, bo według niej leżało to w interesie współobywateli i państwa. Dobitnie stwierdziła, że

Musi ustać to, co było dotą: kształtowanie świata pod kątem widzenia wyłącznie męskim, dla dogodzenia interesom mężczyzn. ... Tak się utarło, że sprawy najważniejsze są decydowane wyłącznie przez mężczyzn: $z$ nich składają się komisje ustawodawcze, oni biorą udział w konferencjach, majacych za zadanie regulowanie najważniejszych zagadnień życia. Oni konstruuja, oni rekonstruuja i zawsze stale decyduja ${ }^{14}$.

W każdym roku nieregularnie ukazywały się numery specjalne. Były poświęcone zagadnieniom najszerzej pojętej kultury lub twórczości kobiet z różnych krajów. Wśród nich odnajdujemy nr 20 z 13 maja 1928 r. w całości poświęcony szkolnictwu żeńskiemu w Polsce w latach 1918-1928. Helena Witkowska w swoim artykule zatytułowanym Wychowanie obywatelskie szczególną uwagę skupiła na zagadnieniu konieczności politycznego uświadamiania kobiet i kształtowania ich „zmysłu państwowego"15. Była zwolenniczką wprowadzenia kultury obywatelskiej jako podstawy wychowawczej, także do instytucji pozaszkolnych, popularyzowania wiedzy o państwie w różnych poziomach kształcenia, wydawania odpowiedniej literatury, zakładania klubów politycznych, które przygotowywałyby kobiety do służby państwowej.

Numer 35 z 26 sierpnia 1928 r. zadedykowano kobiecie bułgarskiej. Powstał dzięki pomocy ministra Vladimira Robeffa, za co redakcja oficjalnie podziękowała, oraz wielu autorów z Bułgarii. $Z$ kolei nr 38 z 16 września 1928 r. poświęcono sprawom dziecka i matki, wspierając tym samym Tydzień Dziecka ogłoszony przez Polski Komitet Opieki nad Dzieckiem. Skupiono się na zagadnieniach społecznych wartości ma-

13 Teodora Męczkowska, „Do czego dą̇̇ymy?”, 1.

14 Ibidem, 2-3.

15 Helena Witkowska, „Wychowanie obywatelskie”, Kobieta Wspótczesna, nr 20, 1928, 28. 
cierzyństwa oraz na tym, czy należy wychowywać dzieci w instytucjach społecznych, czy wspierać opiekę nad nimi w ich własnych domach.

$\mathrm{Na}$ specjalna uwage zasługuje nr 45 z 4 listopada 1928 r., dedykowany pamięci kobiet poległych w walce o wolność. Wydanie tego numeru poprzedził apel Komisji Historycznej Pracy Kobiet w Walkach o Niepodległość, zamieszczony w 23 numerze „Kobiety Współczesnej”16, do wszystkich członkin organizacji wojskowych i pomocniczych, by pomogły zebrać dokumenty i osobiste wspomnienia dotyczące udziału Polek w walkach narodowowyzwoleńczych. Wydźwięk artykułów numeru specjalnego pisma był zachętą dla czytelniczek, aby poczuwały się do dziedzictwa poległych i dalej niosły ich idee poprzez bycie czynnym obywatelem w wolnej Polsce. Miało się to wyrażać m.in. w tym, żeby działać w ramach organizacji politycznych, startować w wyborach oraz głosować. Uczczono pamięć kilkudziesięciu dzielnych Polek.

Numer niepodległościowy, 46, ukazał się 11 listopada 1928 r. Swoje apele i wspomnienia zamieściły w nim znane polskie pisarki okresu dwudziestolecia międzywojennego: Maria Kuncewiczowa, Maria Dąbrowska, Stanisława Kuszelewska, Helena Boguszewska, Wanda Wasilewska, posłanka Jadwiga Dziubińska i inne autorki. Wspomnienia kurierki Wandy Wasilewskiej drukowano w odcinkach w kolejnych numerach ${ }^{17}$.

„Kobieta Współczesna” była pismem wyraźnie postępowym, nawiazywała do tradycji feministycznych, propagowała piórem Cecylii Walewskiej sylwetki kobiet, które czynnie walczyły o równouprawnienie, wydane później jako książka pt. W walce o równe prawa. Nasze bojownice (Warszawa 1931). Redakcja polecała ja, żeby kobiety w kraju wiedziały, które $z$ nich walczyły o ich równe prawa w Polsce ${ }^{18}$. W publikacji opisano sylwetki najbardziej zasłużonych działaczek $z$ okresu walki o równouprawnienie: Pauliny Kuczalskiej-Reinschmidt, Józefy Bojnowskiej, dr Anny Tomaszewicz-Dobrskiej, Teodory Mączkowskiej, dr Justyny Budzińskiej-Tylickiej, Heleny Weychert, Eugenii Waśniewskiej, dr filozofii Romany Pachuckiej, Zofii Stankiewiczówny, Władysławy Weychert-Szymanowskiej, Anny z Paradowskich-Szelagowskiej, dr filozofii Julii Dickstein-Wieleżyńskiej, dr Melanii Bornstein-Łychowskiej, Wan-

\footnotetext{
16 „Wezwanie”, Kobieta Współczesna, nr 23, 1928, 17.

17 Wanda Wasilewska, „Ze wspomnień kurierki. Cz. 2, Związek Pracy Obywatelskiej Kobiet”, Kobieta Współczesna, nr 47, 1928, 8-9; Cz. 3, Kobieta Współczesna, nr 48, 1928, 12; Cz. 4, Kobieta Współczesna, nr 49, 1928, 10.

18 Kobieta Współczesna, nr 4, 1931, 23.
} 
dy Opęchowskiej, Marii Skłodowskiej-Curie, dr Józefy Joteyko, dr Zofii Daszyńskiej-Golińskiej, dr Józefy Kodisowej, dr Michaliny Stefanowskiej, Kazimiery Bujwidowej, Marii Turzymy, Marii Dulębianki, Heleny Witkowskiej, Jadwigi Petrażyckiej-Tomickiej, Marii Gerżabkowej, Melanii Rejchmanowej (I. Orka), Marii Szeligi.

Propagowano wzorce postaw kobiecych, $z$ których należało czerpać, zarówno z kraju, jak i z zagranicy. Przykładowo zapoznano czytelniczki pisma ze znana wychowawczynią i nauczycielką młodzieży okresu zaborów Jadwiga Sikorską, która uważała, że „Ojczyznę buduje się na charakterach"19. Prezentowano kobiety, które pracowały na ważnych stanowiskach, jak np. pochodzaca z ziemiańskiej rodziny Stanisława Paleolog, była obrończyni Lwowa (1918) i Warszawy (1920) oraz kurierka, członkini Ligi Kobiet, która pełniła funkcję aspiranta (najniższy stopień oficerski w policji) w policji kobiecej w Warszawie, dowodząc VI Brygada Sanitarno-Obyczajowa ${ }^{20}$. Doktor Helena Woniczek omówiła działalność naukową dr Józefy Joteyko, która od 1926 r. była docentem na Uniwersytecie Warszawskim oraz redaktorem naczelnym kwartalnika „Polskie Archiwum Psychologii" ${ }^{21}$. Redakcja na łamach pisma zamieściła duży nekrolog po śmierci „uczonej o sławie europejskiej” 24 kwietnia 1928 r. $^{22}$, a także poświęciła numer specjalny, 22 z 27 maja 1928 r. dla uczczenia zasług wielkiej Polki.

Opisano działalność pedagogiczna i społeczną wykształconej za granicą Marii Weryho-Radziwiłłowiczowej, twórczyni „Ogródków dziecięcych” w Warszawie ${ }^{23}$. Cecylia Walewska przywołała postać kompozytorki, nauczycielki, autorki tekstów pieśni i programu nauczania śpiewu w przedszkolach - Ryty Gnus ${ }^{24}$.

Każdy sukces na arenie międzynarodowej odnoszony przez polskie kobiety szczegółowo omawiano. Takim przykładem jest podanie za angielskim „The Vote” z 8 czerwca 1928 r., że na pierwszym plenarnym zebraniu Międzynarodowej Konferencji Pracy w Genewie, na którym był rozpatrywany projekt nowej konwencji w sprawie sposobów ustalania

19 S.Sz., „Z życia ś.p. Jadwigi Sikorskiej”, Kobieta Współczesna, nr 2, 1928, 5; Teodora Męczkowska, „Cieniom Jadwigi Sikorskiej”, Kobieta Współczesna, nr 2, 1928, 5-6.

20 „Komendantka policji kobiecej”, Kobieta Współczesna, nr 3, 1928, 19.

21 Helena Woniczek, „Z niwy naukowej”, Kobieta Wspótczesna, nr 6, 1928, 2-4.

22 Kobieta Współczesna, nr 19, 1928, 2.

23 N.S., „Maria Weryho-Radziwiłłowiczowa”, Kobieta Współczesna, nr 9, 1928, 7-8.

24 Cecylia Walewska, „Ryta Gnus”, Kobieta Współczesna, nr 16, 1928, 15-16. 
minimum płacowego, specjalistka w dziedzinie norm pracy, odszkodowań i ubezpieczeń pracowników Eugenia Waśniewska $z$ Polski wygłosiła przemówienie, które wywołało burzliwa dyskusję ${ }^{25}$. Delegatka przypomniała część XIII traktatu wersalskiego, na którym opiera się Międzynarodowa Organizacja Pracy, że w § 427 ustalono zasadę równej płacy za równa pracę. Helena Ceysingerówna przeprowadziła $z$ nia trzygodzinny wywiad, który wydrukowano w kolejnych numerach pisma ${ }^{26}$.

Irena Jabłowska odwiedziła kobietę nowego czasu - nestorkę dziennikarstwa polskiego Bronisławę Neufeldównę, redaktorkę „Nowin”, „Gazety Polskiej”, „Gazety Handlowej”, „Kuriera Warszawskiego”, „Kuriera Codziennego”, „Tygodnika Ilustrowanego”, „Swiata”, „Sfinksa”, „Epoki”, tłumaczkę powieści i dramatów (znała cztery języki obce) ${ }^{27}$. Zaprezentowano jej sylwetkę, pomimo że w jej działalności zagadnienia estetyczne przeważały nad społecznymi czy politycznymi.

Udostępniano informacje na temat działaczek różnych ugrupowań kobiecych na świecie. Czytelniczki poznały ruch społeczny kobiet w Austrii. Maria Ankiewiczowa opisała swoje odwiedziny w Wiedniu u Gizeli Urban - działaczki społecznej o lotnym umyśle, z pogłębiona refleksja i szeroka skala zainteresowań, byłej publicystki „Neues Wiener Journal”28. Reprezentowała najsilniejszą organizację kobiet zrzeszająca wszystkie zwiazki i towarzystwa feministyczne - Bund der Öesterreichischer Frauenvereine. Szeroko opisywano wizytę w Polsce Emilii Napieralskiej, przewodniczącej Związku Polek w Chicago, największej organizacji kobiet na emigracji w Ameryce ${ }^{29}$. Wielokrotnie podkreślano, że indywidualność kobiety w Ameryce „wyprzedza europejską siostrę swoja samodzielnością i przedsiębiorczością"30, propagowano ich działalność polityczną i społeczna, szczególnie kobiet polskiego pochodzenia, takich

\footnotetext{
25 „Sukces posłanki Eugenii Waśniewskiej w Genewie”, Kobieta Współczesna, nr 26, 1928, 16.

${ }^{26}$ Helena Ceysingerówna, „Polka na forum międzynarodowym”, Kobieta Wspótczesna, nr 32, 1928, 2-4; Eadem, „Międzynarodowe kongresy społeczne w Paryżu. Wywiad z posłanką E. Waśniewska”, Kobieta Współczesna, nr 33, 1928, 2-3.

27 Irena Jabłowska, „U nestorki dziennikarek polskich”, Kobieta Współczesna, nr 37, 1928, 5.

28 Maria Ankiewiczowa, „Moja wizyta u Gizeli Urban”, Kobieta Współczesna, nr 5, 1931, 14-15.

${ }^{29}$ K. Wacki, „Gość z Ameryki - Emilia Napieralska”, Kobieta Współczesna, nr 4, 1928, 14-15; Helena Ceysingerówna, „Wywiad z panią Emilią Napieralską”, Ibidem, 15.

30 Np. X.W. Kneblewski, „Kobieta w Ameryce”, Kobieta Współczesna, nr 18, 1928, 13-15.
} 
jak Marta Mazurowska ${ }^{31}$. Informowano o ich wizytach w Polsce ${ }^{32}$. W tym celu redakcja periodyku włączała się w różne inicjatywy, które pomagały kobietom obrać właściwa drogę życiowa. Tygodnik drukował np. cykl odczytów na temat różnych zawodów i roli, jakie w nich moga odegrać kobiety, powstałych $z$ inicjatywy Stowarzyszenia Kobiet $z$ Wyższym Wykształceniem $z$ Krakowa ${ }^{33}$. Opisano działalność polityczną Marii Urbańskiej, która w latach 1920-1922 była przedstawicielka okręgu wyborczego New Jersey, a w 1925 r. wygrała wybory do legislatury stanowej i sprawowała mandat do 1927 r., a także była twórczynią Polsko-Amerykańskiej Ligi Kobiet ${ }^{34}$.

Czytelniczki zapoznano też z pracami organizacji kobiecych w Austrii $^{35}$, Chrześcijańskich Związków Zawodowych Kobiet w Belgii z Wiktoria Cappe na czele ${ }^{36}$, Rady Narodowej Kobiet Czeskich, zrzeszających wszystkie zwiazki zawodowe kobiece w tym kraju ${ }^{37}$, na Łotwie (miesięcznik „Kobieta Przyszłości” założony w 1923 r. $)^{38}$, w Hiszpanii ${ }^{39}$, Holandii ${ }^{40}$, Niemczech $^{41}$, Szwajcarii (brak praw politycznych) ${ }^{42}$, Szwecji ${ }^{43}$, Wielkiej

31 Irena Jabłowska, „Sylwetki Polek w Ameryce”, Kobieta Współczesna, nr 41, 1928, 14-15.

32 Maria Rodziewicz, „Mili Goście, swojacy - witajcie...”, Kobieta Współczesna, nr 23, 1928, 2; Maria Krzyżanowska, „Pielgrzymka Związku Polek z Ameryki”, Kobieta Wspótczesna, nr 26, 1928, 18.

${ }^{3}$ Helena Witkowska, „Zawody społeczne”, Kobieta Współczesna, nr 24, 1928, 2-3; Zofia Szybalska, „Nauczycielstwo”, Kobieta Współczesna, nr 25, 1928, 2-3; Wanda Buraczewska, „Kobieta inżynier”, Kobieta Wspótczesna, nr 26, 1928, 2; Irena Laskowska, „Kobieta - inżynier chemik”, Kobieta Współczesna, nr 34, 1928, 2-3; Jadwiga Zawirska, „Różnice psychiczne pomiędzy kobietą i mężczyzną a wybór zawodu”, Kobieta Współczesna, nr 39, 1928, 3-5; Wanda Wisłocka, „Zawód lekarski”, Kobieta Współczesna, nr 40, 1928, 2-5; Teresa Kulczyńska, „Pielęgniarstwo”, Kobieta Współczesna, nr 47, 1928, 2-3.

34 Irena Jabłowska, „Sylwetki Polek z Ameryki”, Kobieta Współczesna, nr 30, 1928, 11-12.

35 „Rezultaty wyborów do parlamentu austriackiego”, Kobieta Współczesna, nr 7, 1931, 20.

36 Z.B., „Z Belgii”, Kobieta Współczesna, nr 22, 1928, 18-19; Helena Siemieńska, „W walce o byt", Kobieta Wspótczesna, nr 15, 1931, 3-4.

37 „Prace Czeskiej Rady Narodowej Kobiet”, Kobieta Współczesna, nr 12, 1928, 19.

38 „Ruch kobiecy na Łotwie”, Kobieta Współczesna, nr 28, 1928, 14-15.

39 „Kobiety w parlamencie hiszpańskim, Związek Pracy Obywatelskiej Kobiet”, Kobieta Wspótczesna, nr 42, 1928, 19.

40 „Z krainy tulipanów”, Kobieta Współczesna, nr 50, 1928, 19.

41 Karolina Bielańska, „Wyzwolona Penelopa”, Kobieta Współczesna, nr 52/53, 1928, 19-20.

42 Stanisława Adamowiczowa, „Ruch kobiecy w Szwajcarii”, Kobieta Współczesna, nr 51, 1928, 2-4.

43 Stanisława Goryńska, „Z wycieczki do Szwecji”, Kobieta Współczesna, nr 40, 1928, 18-19. 
Brytanii $^{44}$, we Włoszech ${ }^{45}$. Omówiono ruch kobiecy czarnych mieszkanek w Afryce Południowej ${ }^{46}$, a także w Stanach Zjednoczonych Ameryki Północnej ${ }^{47}$ oraz w krajach azjatyckich ${ }^{48}$. Odnotowano prasę zagraniczna dla kobiet, szerzacą idee kobiety-obywatelki w różnych krajach ${ }^{49}$.

Wzmiankowano o stuleciu urodzin bojowniczki o prawa kobiece na świecie, Angielki Józefiny Butler, polecając równocześnie jej książkę pt. Mój pochód krzyżowy. Zarysy autobiograficzne żywota i pracy (z przedmowa Stanisława Posnera, Warszawa 1906) ${ }^{50}$.

14 czerwca 1928 r. zmarła w Londynie Emmeline Pankhurst brytyjska działaczka społeczna, jedna $z$ założycielek angielskiego ruchu sufrażystek, najważniejsza działaczka na rzecz przyznania kobietom praw wyborczych przed I wojna światowa w Wielkiej Brytanii. Stanisława Goryńska opisała założona przez nią organizację Women's Social and Political Union i agresywne, zdeterminowane sposoby działania $\mathrm{w}$ imię hasła: Votes for Women (Prawo głosowania dla kobiet) ${ }^{51}$.

Śledzono działalność polityczna Polek w międzynarodowych instytucjach, jak np. Jadwigi Romerówny w Lidze Narodów, gdzie ta wykształcona za granica kobieta zajmowała się przeciwdziałaniem handlu dziećmi i kobietami oraz opieka nad dzieckiem ${ }^{52}$.

Każdy numer, a w szczególności rok wyborów w Polsce międzywojennej, obfitował $\mathrm{w}$ artykuły uświadamiajace kobietom, że powinny czynnie włączyć się w walkę o swoje prawa jako obywatelki. Pisano na poważnie, czasem ironicznie. Przykładowo anonimowa autorka w styczniu 1928 r. w artykule pt. Kobiety a polityka nie kryła, że

\footnotetext{
44 „Angielki przygotowują się do nowych wyborów parlamentarnych, Zwiazek Pracy Obywatelskiej Kobiet”, Kobieta Współczesna, nr 44, 1928, 17-18; „Jutrzenka ruchu feministycznego w Anglii”, Kobieta Współczesna, nr 49, 1928, 19; Helena Siemieńska, „W walce o byt", Kobieta Wspótczesna, nr 15, 1931, 3-4.

45 "Ciche zwycięstwo feminizmu włoskiego”, Kobieta Współczesna, nr 3, 1931, 16.

46 Z.B., „Sprawa kobieca w Afryce”, Kobieta Współczesna, nr 26, 1928, 19.

47 „7 kobiet w parlamencie Stanów Zjednoczonych”, Kobieta Współczesna, nr 9, 1931, 19.

48 Anna Paradowska-Szelagowska, „Ruch kobiecy na Wschodzie”, Kobieta Współczesna, nr 8, 1931, 16; „Kongres Kobiet Hinduskich”, Kobieta Współczesna, nr 15, 1931, 18-19. 49 Anna Paradowska-Szelagowska, „Zagraniczna prasa kobieca”, Kobieta Współczesna, nr 16, 1931, 3-4.

50 Czesława Wojeńska, „Józefina Butler (1828-1928)”, Kobieta Współczesna, nr 24, 1928, 19.

51 Stanisława Goryńska, „Emmeline Pankhurst. Wódz sufrażystek”, Kobieta Współczesna, nr 29, 1928, 5-6.

52 Maria Krzyżanowska, „Rozmowa z panią Jadwiga Romerówną. Związek Pracy Obywatelskiej Kobiet”, Kobieta Współczesna, nr 44, 1928, 4-5.
} 
Równouprawnienie polityczne kobiet ma w sobie coś ze zjaw, z którymi spotykamy się na seansach spirytystycznych, ... jak one, materializuje się tylko na pewien krótki czas i pewnych tylko warunkach - na seansach przedwyborczych. Wtedy to ze strony augurów politycznych wypowiadane sa tajemnicze zaklęcia, $z$ których wynika, że w tej jedynej chwili, gdy zjawa praw politycznych kobiet nabiera fizycznej konsystencji, „równouprawnione” przecież obywatelki głosować powinny na listę nr taki a taki. W minutę po wyborach zjawa znika ... i niechaj się nikt już na nią nie powołuje. ... Natomiast znów staje do oczu twarda rzeczywistość: zarobki robotnic przy równowartości pracy są o połowę mniejsze od zarobków mężczyzn ${ }^{53}$.

Ciekawą kwestia jest to, że autorka za ten stan rzeczy winiła same kobiety, które według niej nie lubia polityki, nie podejmuja zdeterminowanej walki $z$ mężczyznami, bojąc się konfrontacji $z$ oszczerstwami i potwarzami. Przypomniała zasługi kobiet przed odzyskaniem przez Polskę niepodległości, kiedy brały one czynny udział w walce narodowowyzwoleńczej na różnych polach. Sarkastycznie przypomniała: „I to ciekawe, że nikt im tego wówczas nie wzbraniał. ... Nikt nie nakazywał im, by przynosiły pozwolenia od mężów na przewóz przez rosyjską granicę broni, dynamitu, bibuly propagandowej. Za tę politykę bowiem nie otrzymywało się wówczas pensji, orderów, nimbu sławy"54. Ganiła jednak kobiety, że odwróciły się od współczesnej polityki, która stała się dla nich zbyt brudna. Uważała, że winą kobiet było oddanie we władanie mężczyznom świata polityki, że nie skorzystały z przysługujących im praw. Nalegała, by kobiety stworzyły „zorganizowane ośrodki siły politycznej, z którymi mężczyźni musieliby się liczyć, każde ich stronnictwo i rząd”. Autorka wierzyła, że jest to tylko okres przejściowy.

W przełomowych momentach wyborów do sejmu zalecano pogłębione refleksje w kwestii oferty różnych partii politycznych, by „w powodzi szumnych haseł rzucanych na wiecach, odnaleźć wskazania, które nie są tylko bańką mydlana, ... które nie są straszakiem politycznym, demonstrowanym podstępnie do otumaniania ludzi niewyrobionych, które nie są kłamstwem powtarzanym przez tych, którzy nie wierzą we własne

53 „Kobiety a polityka”, Kobieta Współczesna, nr 2, 1928, 2.

54 Ibidem. 
słowa”55. Redakcja deklarowała, że „pismo nasze nie stanie w rzędzie krzykliwej agitacji wyborczej, nie odda swych łamów do użytku tej lub innej partii, natomiast w szeregu artykułów poruszać będzie zagadnienia, które w dobie wyborów narzuca samo życie, a od których nie wolno odwracać oczu, jeżeli się chce być świadomym obywatelem państwa" ${ }^{\text {" }}$. Jedna $z$ autorek przestrzegała przed niebezpiecznym dla jedności ledwie odrodzonego państwa wybujałym indywidualizmem. Dalej pisała:

Zaostrzać antagonizmy, rozjątrzać walki wewnętrzne czy to klasowe, lub narodowościowe, czy stronnicze, utrudniać akcję tym, co ster rzadu ująwszy silną ręka, dążą do wzmocnienia władzy wykonawczej, by móc wrogim siłom zewnętrznym przeciwstawić Polskę skonsolidowana i silna - to znaczy ryzykować tym, co naród każdy poczytuje za najwyższe swoje dobro i najświętsze $z$ praw - niepodległy byt polityczny ${ }^{57}$.

Zgodnie $\mathrm{z}$ deklaracja redakcji pisma regularnie zamieszczano $\mathrm{w}$ nim rozważania przedwyborcze. Helena Ceysingerówna, zachęcając do wzięcia czynnego udziału w wyborach, przypominała o prawach konstytucyjnych, analizowała zagadnienia polityki wewnętrznej i zewnętrznej, pisała o tym, że: „Istnieje za oceanem, w Ameryce Północnej gotowy wzór ... demokratycznego ustroju, który posiada ... cechy stałości, niezbędne do uzyskania wewnętrznego ładu i uczynienia Państwa tak silnym, by nie przedstawiało łatwej zdobyczy dla zewnętrznych wrogów"58, sugerując, że w takim kierunku zmierza obóz rządowy. Przekonywała, że ten rząd złożony z

najrozmaitszych ugrupowań, $z$ ludzi o bardzo odmiennych przekonaniach społecznych i politycznych, których łączy jedna idea: że Polsce potrzeba dziś i jutro silnego rząu, silnej władzy wykonawczej, niezależnej od burzliwości partii, od ich walk i antagonizmów ${ }^{59}$.

W rubryce „Ruch polityczny wśród kobiet” w 1928 r. relacjonowano przygotowania do starcia wyborczego i przedstawiano kandydatki Narodowej Organizacji Kobiet, Wydziału Kobiecego PPS (Zofia Praussowa, dr Justyna Budzińska-Tylicka), Demokratycznego Komitetu Wyborczego

55 Helena Ceysingerówna, „W przełomowym momencie”, Kobieta Współczesna, nr 3, 1928, 5.

56 „Przyp. Redakcji”, Kobieta Współczesna, nr 3, 1928, 5.

57 Helena Ceysingerówna, „W przełomowym momencie”, 5.

58 Eadem, „Z rozważań przedwyborczych”, Kobieta Współczesna, nr 5, 1928, 4-5.

59 Ibidem, 5. 
Kobiet Polskich (popierający idee Józefa Piłsudskiego; Kazimiera Grunterówna $z$ Kielc - urzędniczka sądowa, działaczka Ligi Kobiet i Komitetu Obrony Państwa 1920 r.) oraz innych organizacji ze stolicy i pozostałych części Polski ${ }^{60}$. Michalina Grekowicz-Hausnerowa ze Lwowa przypomniała, że kobiety lwowskie pójda do wyborów dopiero drugi raz. Pierwsze bowiem w 1919 r. miały w dzielnicy małopolskiej charakter uzupełniający i odbyły się na podstawie dawnej austriackiej ordynacji wyborczej, a zatem bez udziału kobiet ${ }^{61}$. W kolejnych wyborach do sejmu i senatu w 1922 r. kobiety lwowskie zgłosiły własna - jedyną wówczas - listę kobiecą:

Grono kobiet chciało całej falandze elementów zużytych w publicznym życiu, ... przeciwstawić siły politycznie młode, wolne od sztuki wszelkich krętactw, zaciekłości partyjnej i sprzedajności, ożywione dobrymi chęciami służenia państwu i przeciwstawiające ... zdecydowany program społeczny: walkę o prawdziwe równouprawnienie kobiety, troskę o los i wychowanie wszystkich bez wyjattku dzieci, opiekę nad chorymi i starcami, zwalczanie prostytucji i alkoholizmu ${ }^{62}$.

Na czele listy kobiecej do sejmu stała nauczycielka ze szkoły średniej, a w 1928 r. dyrektorka Seminarium Nauczycielskiego w Lwowie - Maria Jaworska. Akcja przedwyborczą od stycznia 1928 r. w mieście nad Pełtwią zajmowały się: Maria Jaworska, przewodniczacca Ligi Kobiet Jadwiga Bogdanowiczowa, Wanda Norwid-Neugebauerowa (późniejsza senator), prof. Maria Strońska, rzeźbiarka i malarka, radna miasta Lwowa - Luna Amalia Drexlerówna.

W numerze 5 z 1928 r. ukazało się ogłoszenie redakcji, w którym czytamy:

Stoimy na progu nowych wyborów. Jest to odpowiedni dla ogółu kobiet moment, by zsumować dorobek prac naszych przedstawicielek, które $\mathrm{w}$ ubiegłych kadencjach piastowały godności poselskie i senatorskie, a zarazem by sformułować żądania i dezyderaty, które ogół wyborczyń stawia przyszłym posłankom i senatorkom. W tym celu w miesiącu lutym Redakcja „Kobiety Współczesnej” wyda specjalny numer pt. „Kobieta w Sejmie i Senacie”. Poza tym w numerze 6. naszego tygodnika

60 „Ruch polityczny wśród kobiet”, Kobieta Współczesna, nr 5, 1928, 16-17.

61 Maria Grekowicz-Hausnerowa, „Ze Lwowa”, Kobieta Współczesna, nr 5, 1928, 16-17.

62 Ibidem, 16. 
ogłosimy ankietę, która pozwoli kobietom wypowiedzieć się na temat spraw, które posłanki i senatorki, jako rzeczniczki ogółu kobiet, będa musiały poruszyć i bronić na terenie przyszłego Sejmu ${ }^{63}$.

Redakcja dotrzymała słowa w tej kwestii, wydając 4 marca 1928 r. numer 10 jako numer specjalny: „Zadania kobiet w Sejmie i Senacie". Numer otwiera drzeworyt zdobiący kartę tytułową książki Marcina Bielskiego pt. Sejm niewieści, wydanie z 1595 r. Teodora Męczkowska w artykule Kobiety - Sejm - Życie przywołała na wstępie artykuły 12 i 13 Konstytucji z 17 marca 1921 r., głoszace, że „prawo wybierania ma każdy obywatel polski, bez różnicy płci, który w dniu ogłoszenia wyborów ukończył 21 lat” i „prawo wybieralności ma każdy obywatel, mający prawo wybierania do Sejmu, o ile ukończył 25 lat”; nadto „§ 36 dodaje: "Wyborca do Senatu musi mieć ukończonych lat 30, wybierany ukończonych lat 40"”64. Przypomniała, że w pierwszym Sejmie Ustawodawczym zasiadało siedem posłanek; aktualnie w sejmie dziewięć, a w senacie trzy. Zaznaczyła jednak, że udział kobiet w życiu politycznym kraju jest niewystarczający i że przyczyny tkwią w samych kobietach, które nie chca się angażować, i w mężczyznach, którzy nie mogą się pogodzić z utratą supremacji wobec kobiet. Poza tym podjęła watek braku rzeczniczek sprawy kobiecej, zarzucając posłankom, że „oddawały się bez zastrzeżeń na usługi partii, stając się w ich rękach biernym, ale niezmierne pożytecznym narzędziem" ${ }^{65}$. Apelowała o wyłanianie kandydatek $z$ charakterem, które umiałyby w sejmie walczyć o interesy Polek. Na dowód nierówności, których nie zniósł § 96 Konstytucji, mówiący o tym, że wszyscy obywatele sa równi wobec prawa, przytoczyła fakty unaoczniające, że wśród inspektoratów szkół powszechnych w całym kraju nie ma ani jednej kobiety na stanowisku kierowniczym, że np. w Małopolsce wszystkie seminaria żeńskie i gimnazja kierowane sa przez mężczyzn, że np. w Warszawie na 400 lekarek żadna nie piastuje stanowiska lekarza naczelnego, że np. w województwie śląskim zamężne kobiety nie mogą pracować w szkołach publicznych i wiele innych ${ }^{66}$. Wyraziła opinię, że bez pracy zawodowej kobiet współczesne społeczeństwo nie może się obejść i że ich praca w niczym nie ustępuje pracy mężczyzn.

\footnotetext{
${ }^{63}$ Kobieta Współczesna, nr 5, 1928, 18; Kobieta Współczesna, nr 6, $1928,17$.

64 Teodora Męczkowska, „Kobiety - Sejm - Życie”, Kobieta Współczesna, nr 10, 1928, 2.

65 Ibidem.

66 Ibidem, 3.
} 
Nela Samotyhowa podzieliła się refleksjami na temat wartości kobiet w pracach parlamentu, uznając ich nieobecność w życiu politycznym za anachronizm ${ }^{67}$.

Wanda Grabińska pochyliła się nad kobietami w zawodach prawniczych, uzmysławiając, że to dla nich nowe pole działania, bo do tej pory nie były do nich dopuszczane ${ }^{68}$. Zwróciła uwage na chaos ustawodawczy panujący w tej materii życia publicznego w różnych dzielnicach kraju, oczekujac od przyszłych senatorek i posłanek „energicznej akcji w celu uregulowania tej sprawy"69. Wykazała, że pomimo zapisów konstytucyjnych w adwokaturze i sądownictwie równouprawnienie jest czystą fikcja, że kobiety muszą walczyć z uprzedzeniami świata mężczyzn. Jako godny przykład determinacji odnotowała, że w 1925 r. Helena Wiewiórska zdała egzamin przed Rada Adwokacka i jako pierwsza adwokatka została przyjęta w poczet palestry warszawskiej. Na terenie byłego Królestwa Kongresowego w ślad za nią podażyły inne prawniczki. Na ziemiach byłego zaboru pruskiego w 1928 r. nadal obowiazywało prawo z 1920 r. (Dz.U. $\mathrm{nr} 11 \mathrm{z}$ dn. 22 marca 1920) blokujące kobietom dostęp do aplikacji sędziowskiej i adwokackiej. W byłym zaborze austriackim zakazu nie było, ale dopiero „w ostatnich czasach zmieniło się na lepsze"70. Natomiast w całym kraju kobiety nie są faktycznie dopuszczane do zawodu sędziego czy notariusza, choć żadne przepisy tego nie zabraniaja.

Dzisiejszy stan rzeczy stwarza taka anomalię, że kobieta będąc posłem czy senatorem, biorac udział w uchwalaniu ustawodawstwa dla całego narodu, nie mając prawnych przeszkód do zostania Prezydentem Rzeczypospolitej lub ministrem sprawiedliwości i mianowania sędziów, sama na stanowisko sędziowskie nie jest dopuszczana ${ }^{71}$.

Autorka widziała ogromną rolę kobiet-sędziów szczególnie w sądownictwie dla nieletnich. Od posłanek i senatorek oczekiwała zaś wznowienia walki z przestępczościa dzieci poprzez utworzenie odpowiedniej liczby zakładów poprawczych, wychowawczych, schronisk itp.

67 Natalia Samotyhowa, „Wartość współczynnika żeńskiego w pracy parlamentu”, Kobieta Współczesna, nr 10, 1928, 4-5.

68 Wanda Grabińska, „Kobieta w sądownictwie”, Kobieta Współczesna, nr 10, 1928, 5-6.

69 Ibidem, 6.

70 Ibidem, 5.

71 Ibidem. 
Nadmienić należy, że redakcja pisma pilnie odnotowywała nowe zaprzysiężenia adwokatek ${ }^{72}$ oraz kobiet na stanowiskach sędziowskich ${ }^{73}$. Wielokrotnie pisano także o tym, że nie ma podstaw prawnych wykluczajacych kobiety od pełnienia obowiązków ławnika. Wzmiankowano, że jeszcze w 1931 r. w dwóch funkcjonujących sądach pracy w Warszawie nie zasiadała żadna kobieta ${ }^{74}$.

Kwestią stosunków pracy najemnej zajęła się Halina Krahelska ${ }^{75}$. Wyraziła przekonanie, że „obowiązkiem kobiet-posłanek, myślących w kategoriach postępu społecznego, będzie dbać o racjonalną rozbudowę ustawodawstwa socjalnego w zakresie pracy kobiet i młodocianych"76. Jako najpilniejsze wymieniła: ochronę pracy kobiet: zorganizowanie poradni położniczych, zakaz zwalniania kobiet w ciaż̇y, wprowadzenie żłobków i przedszkoli dla robotnic fabrycznych, zrównanie płac z mężczyznami; ochronę zdrowia młodzieży dorastającej, zakaz pracy dla młodocianych w szkodliwych warunkach, ograniczenie ich czasu pracy, umożliwienie kształcenia zawodowego i dokształcania młodzieży pracującej.

Helena Ceysingerówna podjęła temat równouprawnienia urzędniczek państwowych, które jeszcze w 1928 r. nie mogły przekroczyć tzw. V szczebla hierarchii służbowej ${ }^{77}$. Doktor Helena Więckowska oczekiwała od posłanek i senatorek, że upomna się o prawa do rzeczywistego równouprawnienia kobiet na stanowiska kierownicze poszczególnych katedr w uniwersytetach, nieograniczonego dostępu kobiet na wydział medyczny i do stypendiów naukowych ${ }^{78}$.

W numerze tym wydrukowano pierwsze głosy czytelniczek, będących odpowiedzią na ankietę ogłoszona w numerze 6: „Które z najważniejszych dla ogółu kobiecego zagadnień społecznych powinno skupić uwagę naszych posłanek i stać się najpilniejszym tematem prac ich

\footnotetext{
72 „Nowy zastęp adwokatek”, Kobieta Współczesna, nr 27, 1929, 18.

73 „Druga kobieta sędzią dla nieletnich w Polsce”, Kobieta Wspótczesna, nr 8, 1931, 18; Irena Jabłowska, „Z sądu dla nieletnich”, Kobieta Współczesna, nr 10, 1931, 5-6; „Jeszcze jedna nominacja kobiety-sędziego", Kobieta Współczesna, nr 14, 1931, 16.

74 Eugenia Waśniewska, „Kobiety w Sądach Pracy”, Kobieta Współczesna, nr 7, 1931, 19.

75 Halina Krahelska, „Najbliższe zadania posłanek”, Kobieta Współczesna, nr 10, 1928, 6.

76 Ibidem.

77 Helena Ceysingerówna, „Urzędniczki państwowe. Równouprawnienie”, Kobieta Wspótczesna, nr 10, 1928, 7-8.

78 Helena Więckowska, „W sprawie równouprawnienia na uniwersytetach”, Kobieta Współczesna, nr 10, 1928, 8.
} 
w nowym Sejmie?”79. Głos zabrały przedstawicielki o różnych poglądach politycznych. Wszystkie jednak zgodnie wskazały, że sprawą najwyższej wagi jest kwestia opieki nad dzieckiem, podpisując się pod myśla Aleksandry Piłsudskiej, która stwierdziła, że „Polska musi być Ojczyzną szczęśliwych dzieci" ${ }^{80}$. Wypowiedziały się też radne miejskie: Anna Brzezińska zwróciła uwagę na walkę $z$ poniżeniem kobiet prostytutek, dr Justyna Budzińska-Tylicka żądała praw dla dzieci nieślubnych, reformy prawa małżeńskiego, zniesienia wszelkich ograniczeń kobiet w prawie cywilnym i handlowym, zrewidowania ustawy o sadownictwie wykluczajaccej kobiety $z$ zawodu sędziego; dołączyła do nich Helena Zaborowska. Pisarki Maria Dabrowska i Maria Rodziewiczówna upomniały się o: zakaz handlu żywym towarem, walkę $z$ alkoholizmem, pracę oświatowa, opiekę nad matką i dzieckiem (uznanie prawa dzieci nieślubnych), reformę sądownictwa (zakaz kary śmierci, przyznanie kobietom prawa dostępu do zawodu sędziego, usankcjonowanie ślubów cywilnych) i reformę pracy. Starszy asystent na Politechnice Warszawskiej dr Alicja Dorabialska, reprezentantka Zwiazku Naprawy Rzeczypospolitej, za priorytet uznała opiekę nad matką i dzieckiem oraz zwalczanie prostytucji. O dostęp do równych płac i wyższych stanowisk upomniała się przewodnicząca Związku Zawodowego Kobiet $z$ Wyższym Wykształceniem, prof. Cezaria Baudouin de Courtenay Ehrenkreutz Jędrzejewiczowa. $Z$ kolei prof. dr Zofia Daszyńska-Golińska uznała, że posłanki i senatorki powinny zwrócić uwage na wykonywanie ustawy antyalkoholowej, politykę mieszkaniowa, równa płacę za tę samą pracę, ochronę pracy kobiet i młodocianych, uzyskanie funduszy na szkolnictwo zawodowe kobiet. Nauczycielka Zofia Iwaszkiewiczowa domagała się zapewnienia opieki dzieciom upośledzonym, a także równouprawnienia w dostępie do wyższych stanowisk i równych płac. Przewodniczaca Koła Pracy Kobiet J. Klawerowa żądała wzniesienia się ponad podziały partyjne w moralnym wychowaniu młodzieży, Janina Jurkiewiczowa natomiast - reformy sądownictwa i opieki nad młodocianymi. Również inne kobiety opowiedziały się za tymi samymi kwestiami, a wśród nich: nauczycielka M. Librachowa, Konstancja Łubieńska i Bronisława Szymkowiakówna (dołączyły postulat walki z chorobami wenerycznymi) z Zarządu Koła Polek, Janina Miedziańska,

79 „Odpowiedzi na ankietę «Kobiety Współczesnej»”, Kobieta Współczesna, nr 10, 1928, 9-13.

80 Ibidem, 9. 
przewodniczaca Komitetu Demokratycznego Kobiet, Zofia Moraczewska, wiceprzewodnicząca Katolickiego Związku Kobiet P. Neronowicz-Szpilewska, prof. Wolnej Wszechnicy Helena Radlińska, Alicja Szelagowska, Cecylia Śniegocka, bojowniczki o równe prawa i zawodowe wykształcenie kobiet Cecylia Walewska i Helena Weychertówna, Eugenia Waśniewska z Klubu Politycznego Kobiet Postępowych, nauczycielka Władysława Weychert-Szymanowska, członek zarządu „Ochrony Kobiet” Władysława Zarembina, a E. Czarnocka i A. Grzybowska z Zarzadu Stowarzyszenia Zjednoczonych Ziemianek dodały, że według nich najważniejszym zadaniem nowego sejmu będzie „szerzenie wśród obywateli poczucia praworządności oraz obywatelskiej odpowiedzialności jednostki”"1.

Karolina Bielańska opisała historię głosów niewieścich stanu szlacheckiego w życiu politycznym państwa polskiego od XVI w. ${ }^{82}$ Drwi $\mathrm{w}$ artykule $\mathrm{z}$ ksiażek, które utrwaliły stereotyp kobiety „trusi i niemowy”: Dworzanina polskiego zwierciadło Łukasza Górnickiego (Kraków 1566), będacego parafraza traktatu $I l$ cortegiano Baltazara Castiglione i Sejmu niewieściego napisanego przez Marcina Bielskiego około 1569 r., a wydanego po jego śmierci w 1586 r., będącego satyrą na współczesną szlachtę, na jej opilstwo, bezprawie, ciemiężenie słabszych. Napisała, że:

Stary satyryk widzi swoich ziomków w barwach tak czarnych, że aby im jak najjaskrawiej dowieść swej pogardy, stawia tezę, paradoksalna zgoła: „kobiety nawet, gdyby im dać rząd w ręce, rządziłyby lepiej”83.

Powracano do historycznych wystapień politycznych polskich kobiet w dziejach narodu oraz do ich zakulisowych działań politycznych. Omówiono np. list zredagowany w imieniu województwa sieradzkiego przez chorażankę Mariannę Walewska, skierowany do króla Stanisława Augusta Poniatowskiego po nadaniu Konstytucji 3 maja w $1791 \mathrm{r}^{84}$

W latach wyborów Polki próbowały organizować się politycznie w różnych kręgach. Informowano o przedwyborczych spotkaniach w różnych regionach Polski. Czytelniczki zapoznane zostały m.in. z ruchami konsolidacyjnymi w Wilnie (Narodowa Organizacja Kobiet, Katolicki Związek Kobiet, Stowarzyszenie im. św. Wincentego à Paulo, Koło Kobiet,

\footnotetext{
81 Ibidem, 13.

82 Karolina Bielańska, „Córki Rzeczypospolitej”, Kobieta Współczesna, nr 10, 1928, 14-15.

83 Ibidem, 14.

${ }^{84}$ Cecylia Walewska, „Ciekawy dokument kobiecy z końca XVIII w.”, Kobieta Współczesna, nr 19, 1928, 5-6.
} 
Demokratyczny Komitet Wyborczy Kobiet Polskich, Organizacja Pracy Społecznej Kobiet) ${ }^{85}$. Inauguracyjny wiec odbył się 2 stycznia 1928 r. w kinie Helios. Wzięło w nim udział 400 delegatek, w tym również z prowincji, dla których zorganizowano kursy propagandy. Kobiety przystapiły do współpracy z Bezpartyjnym Blokiem Współpracy z Rządem, wystawiając swoją kandydatkę $z$ Wilna, nauczycielkę historii z Żeńskiej Szkoły Przemysłowo-Handlowej, zasłużoną działaczkę harcerską i POW, Ewę z Makowskich Gulbinowa.

Opisano pierwsze zebranie Koła Pań przy Radzie Zjednoczenia Stanu Średniego, które miało miejsce 20 stycznia 1928 r. w Warszawie ${ }^{86}$. Celem posiedzenia była próba utworzenia wielkiej organizacji kobiecej pod nazwą Zjednoczenie Mieszczanek, które skupiałoby kobiety mieszkajace w miastach. Do zarządu weszły: Anna Brzezińska, Anna Grabowska, Stefania Skarżyńska, Julia Brudzyńska, Janina Weberowa, Janina Bergtoldowa, Kazimiera Serkowska, Jadwiga Reiffowa. Zdawano relacje z posiedzeń różnych organizacji działających w stolicy, np. Klubu Politycznego Kobiet Postępowych ${ }^{87}$. Jego członkinie były inicjatorkami Demokratycznego Bloku Wyborczego Kobiet Polskich, prowadzac szeroko zakrojona akcję polityczna. Na zebraniu 8 lutego 1928 r. pp. Waśniewska i Bujak-Boguska odczytały sprawozdanie $z$ akcji wyborczej, a p. Fuksówna referat o wyłączeniu kobiet $z$ sądów przysięgłych.

Śledzono działalność kobiet górnośląskich zrzeszonych w Śląskim Towarzystwie Kobiet, liczacym 12 tys. przedstawicielek ludu i inteligencji, którym przewodniczyła włościanka Józefa Baranowska, kandydatka na posłankę okręgu górnośląskiego ${ }^{88}$.

Publicystka Eugenia Gulbinowa za najważniejsze prawo, jakie obywatelom Rzeczypospolitej Polskiej gwarantowała nasza Konstytucja w wolnej Polsce, uznała prawo wyborcze ${ }^{89}$. Wzywała kobiety do czynnego włączenia się w walkę wyborczą, dość naiwnie jednak apelowała, by była to walka czysta, bez „waśni partyjnych, nieuczciwych agitacji,

85 „Ruch przedwyborczy wśród kobiet w Wilnie”, Kobieta Współczesna, nr 7, 1928, 16.

86 „Nowa kobieca organizacja polityczna”, Kobieta Współczesna, nr 6, 1928, 17.

87 „Z działalności Klubu Politycznego Kobiet Postępowych”, Kobieta Współczesna, nr 8, 1928, 17; „Z Klubu Kobiet Postępowych”, Kobieta Współczesna, nr 15, 1931, 16.

88 „Z działalności kobiet górnośląskich”, Kobieta Wspótczesna, nr 11, 1928, 19.

89 E. Gulbinowa, „Kobieta wobec swych praw i obowiązów chwili obecnej”, Kobieta Współczesna, nr 11, 1928, 2. 
podsycania nienawiści klasowych i narodowościowych", w poszanowaniu „własnej godności i broniąc czystej sprawy”90.

Wanda Pełczyńska w swych powyborczych refleksjach w piśmie wyraźnie stwierdzała, że

wpływ kobiet na kształtowanie list wyborczych, ... był znikomy. ... Kobiety spełniły rolę Murzyna, który odrobił swoją robotę i może odejść. Liczba 11 posłanek i senatorek na ogólną liczbę 555 mandatów poselskich mówi sama za siebie. Świadczy ona o tym, że kobieta jako twórczy czynnik w Parlamencie jest ledwo tolerowana ${ }^{91}$.

Wymieniono osiem posłanek i trzy senatorki, które objęły mandaty. $Z$ listy nr 1 - Demokratyczny Komitet Wyborczy Kobiet Polskich: Maria Jaworska ze Lwowa, Eugenia Waśniewska $z$ Warszawy, prof. dr. Zofia Daszyńska-Golińska (senatorka); z listy nr 2 - PPS: Zofia Praussowa (posłanka), Dora Kłuszyńska (senatorka); z listy nr 3 - PSL „Wyzwolenie": Irena Kosmowska, Stanisława Karnicka (posłanki); $z$ listy nr 24 - Stronnictwo Katolicko-Narodowe: Gabriela Balicka, Irena Puzynianka (posłanki). Przedstawicielkami Ukrainek były Milena Natalia Rudnicka (sejm) i Helena Kisielewska (senat). Autorka wyraziła obawę, czy to nikłe zwycięstwo kobiet przyczyni się do wzbudzenia zainteresowania kwestiami Polek w nowym parlamencie.

Nadal nie ustawano w propagowaniu czynnych postaw kobiet w życiu politycznym kraju. Szeroko rozpowszechniano informacje o ich udziale w parlamentach zagranicznych. Zofia Bogórska napisała syntetyczny artykuł na ten temat, począwszy od 1905 r., kiedy Finlandia ${ }^{92}$ jako pierwszy kraj w Europie wprowadziła równouprawnienie obywatelskie kobiet, poprzez Holandię, Węgry, Austrię, Hiszpanię, Czechosłowację, Litwę, Łotwę, Amerykę Północną, Nową Zelandię, Australięe93. Autorka podkreśliła, że:

Bez względu na swa przynależność partyjna, kobiety w parlamentach wszystkich krajów są przede wszystkim rzeczniczkami reform zmierza-

\footnotetext{
90 Ibidem.

91 Wanda Pełczyńska, „Po wyborach”, Kobieta Współczesna, nr 13, 1928, 3.

92 Szeroko omawiano ustawodawstwo w tym kraju, dotyczace kobiet i dzieci, np. Helena Siemieńska, „W walce o byt”, Kobieta Wspótczesna, nr 11, 1931, 3-4.

93 Zofia Bogórska, „Kobiety w parlamentach zagranicznych”, Kobieta Współczesna, nr 15, 1928, 2-4.
} 
jących do uzdrowienia stosunków społecznych, do usunięcia wszelkich krzywd i niesprawiedliwości ${ }^{94}$.

W „Kobiecie Współczesnej” wydrukowano obszerne sprawozdanie z Walnego Zebrania Stowarzyszenia Kobiet z Wyższym Wykształceniem, zasilające listę Demokratycznego Komitetu Wyborczego Kobiet Polskich, które odbyło się w Warszawie w Kasynie Garnizonowym przy Alei Szucha 25 marca 1928 r. ${ }^{95}$ Ze sprawozdania Haliny Jaroszewiczowej, przewodniczącej akcji wyborczej na prowincji, wynikało, że w ciagu dwóch i pół miesiąca utworzono 15 komitetów wojewódzkich, 40 komitetów okręgowych i ponad 400 miejscowych. W tym czasie przeprowadzono 1200 wieców w całym kraju (220 na Śląsku, 130 w Krakowskiem, 100 w okręgu lwowskim, 115 na Wileńszczyźnie itd.). Program Związku zaprezentowano w kolejnym numerze ${ }^{96}$. Cyklicznie powracano do różnych form działalności tej organizacji ${ }^{97}$.

Kontynuowano doniesienia o spotkaniach wielu stowarzyszeń kobiecych. Przykładem był Zjazd Rady Naczelnej Koła Kobiet w dniach 26-27 marca 1928 r. w Warszawie, na którym podjęto m.in. kwestie udziału kobiet w pracy społecznej, zawodowego wykształcenia kobiet, naukowej organizacji pracy, wagi pracy świetlicowej na prowincji, wychowania fizycznego i przysposobienia wojskowego kobiet ${ }^{98}$. Innym razem wzmiankowano Zjazd Stowarzyszenia „Służba Obywatelska” w Warszawie w czerwcu 1928 r., który zrzeszał 15 kół: z Warszawy, Krakowa, Poznania, ze Lwowa, Stanisławowa, z Przemyśla, Rzeszowa, Lublina, Łodzi, Sosnowca, Torunia, Gniezna, Grudziądza, ze Spiska, z Wilna ${ }^{99}$.

Recenzowano książki pisane przez postępowe autorki. Na marginesie publikacji senator dr Zofii Daszyńskiej-Golińskiej pt. Zagadnienia polityki populacyjnej (Warszawa 1927, t. 4 Biblioteki „Gazety Administracji i Policji Państwowej”) Helena Witkowska wykazała, że „współczesna kwestia kobieca przeobraża rodzinę, zmienia układ ekonomiczny i poli-

\footnotetext{
${ }^{94}$ Ibidem, 4.

95 Helena Ceysingerówna, „Zjazd delegatek Demokratycznego Komitetu Wyborczego Kobiet Polskich”, Kobieta Współczesna, nr 15, 1928, 16-17.

96 „Stowarzyszenie Kobiet z Wyższym Wykształceniem”, Kobieta Współczesna, nr 16, 1928, 16.

97 Np. „Nowe stypendium międzynarodowe dla kobiet dla dopełnienia studiów we Francji”, Kobieta Współczesna, nr 50, 1928, 16.

98 C-r, „Zjazd Rady Naczelnej Koła Kobiet”, Kobieta Współczesna, nr 16, 1928, 16-17.

99 „Służba Obywatelska”, Kobieta Współczesna, nr 26, 1928, 17-18.
} 
tyczny społeczeństwa i oddziałuje na kształtowanie się stosunków ludnościowych" ${ }^{100}$. Helena Ceysingerówna przeprowadziła wywiad z Zofia Daszyńska-Golińska, z którego wynika, że senator do polityki weszła „z poczucia obywatelskiego obowiązu, by podtrzymywać rząd Marszałka Piłsudskiego"101. Pania senator najbardziej interesowały w parlamencie sprawy ochrony i ubezpieczenia pracy.

Wnikliwie omawiano także publikacje naukowe z zakresu współczesnego prawa polskiego, jak np. książkę prof. Zygmunta Cybichowskiego pt. Polskie prawo państwowe, t. 1 (1925) i 2 (1927) ${ }^{102}$. Przyglądano się próbom reform prawa małżeńskiego ${ }^{103}$. Drukowano projekty ustaw, np. o sadach dla nieletnich ${ }^{104}$, o przeciwdziałaniu alkoholizmowi ${ }^{105}$, o prawie małżeńskim ${ }^{106}$, o nocnej pracy kobiet ${ }^{107}$. Komentowano zatwierdzone akty prawne, jak np. ustawę $\mathrm{w}$ sprawie pracy kobiet i młodocianych z 2 lipca 1924 r. ${ }^{108}$

Czytelniczki pisma mogły się również zapoznać $z$ wywiadem $z$ posłanką Maria Jaworska ze Lwowa, przedstawicielką Ligi Kobiet, POW, Komitetu Obywatelskiego Kobiet, Klubu Politycznego Kobiet Postępowych, przewodnicząca Stowarzyszenia Kobiet z Wyższym Wykształceniem $^{109}$. Była pierwsza kandydatka listy kobiecej ze Lwowa podczas wyborów w 1922 r. Po wyborach w 1928 r. zasiadała w sejmowych komisjach: oświatowej, opieki społecznej i emigracyjnej. Zapowiedziała walkę o 7-klasowa szkołę powszechna, o ochronę praw kobiety i dziecka.

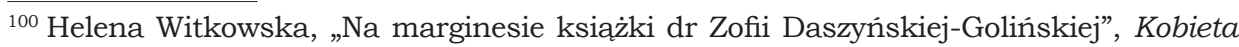
Wspótczesna, nr 18, 1928, 2.

${ }^{101}$ Helena Ceysingerówna, „W poczuciu obowiazku obywatelskiego”, Kobieta Współczesna, nr 25, 1928, 4-5.

102 Np. Stefania Lewartowicz, „Suknia na wyrost». Na marginesie książki prof. Zygmunta Cybichowskiego", Kobieta Współczesna, nr 49, 1928, 8.

${ }^{103}$ L.R., „W poszukiwaniu nowych form małżeństwa”, Kobieta Współczesna, nr 27, 1929, 6-7.

${ }^{104}$ Wanda Grabińska, „Projekt ustawy o sadach dla nieletnich. Z cyklu «W obronie dziecka”", Kobieta Współczesna, nr 16, 1928, 2-4.

${ }^{105}$ Stanisława Adamowiczowa, „Na marginesie nowej ustawy antyalkoholowej”, Kobieta Współczesna, $\mathrm{nr}$ 7, 1931, 5-6.

${ }_{106}$ Zofia Zandowa, „Nowe prawo małżeńskie”, Kobieta Współczesna, nr 13, 1931, 2-3; Grażyna Szmurłowa, „Zasady projektu prawa małżeńskiego”, Kobieta Współczesna, nr 15, 1931, 2-3.

107 „Praca nocna kobiet”, Kobieta Współczesna, nr 13, 1931, 18.

${ }^{108}$ I[rena] J[abłowska], „Opieka nad dzieckiem robotnicy”, Kobieta Współczesna, nr 9, 1931, 16-17.

${ }^{109}$ Helena Ceysingerówna, „Wśród prawodawców”, Kobieta Współczesna, nr 26, 1928, 3-4. 
Zapewniła, że „stara się nie stracić żywego czucia $z$ wolą i dążeniami wyborców"110.

Starano się pokazywać, że działanie posłanek widoczne jest w sejmie poprzez czynny udział we wszystkich komisjach ${ }^{111}$. Maria Jaworska objęła funkcję przewodniczącej komisji oświatowej, co zdarzyło się po raz pierwszy w historii polskiego parlamentaryzmu. Zofia Moraczewska była kierowniczką komisji ds. emigracji , Halina Jaroszewiczówna natomiast kierowniczką komisji opieki społecznej i zastępca w komisji ochrony pracy oraz regulaminowej. Maria Bałabanówna była członkinią komisji społecznej i zastępca członka w komisji oświatowej, Eugenia Waśniewska weszła zaś do komisji: ochrony pracy, konstytucyjnej oraz prawniczej. Zofia Berbecka zasiliła komisję wojskowa. Janinę Kirtiklisowa powołano na członkinię dwóch komisji: opieki społecznej - oraz emigracyjnej. Kazimiera Marczyńska weszła w skład komisji oświatowej i społecznej, a Ludwika Wolska - komisji spraw zagranicznych i pełniła funkcję zastępcy w komisji administracyjnej.

Stałym elementem składowym „Kobiety Współczesnej” były artykuły wspomagajace patriotyczne i obywatelskie wychowanie dzieci i młodzieży. Służyły temu m.in. hufce przysposobienia wojskowego ${ }^{112}$. Informowano też o nowościach skierowanych do kobiet w programach Polskiego Radia, o przekształceniu audycji „Kącik dla kobiet” w „Kronikę kobieca" ${ }^{113}$. Upatrywano w tym doskonały kanał propagandy kwestii kobiecej.

Redakcja skwapliwie informowała o powstaniu nowych kobiecych stowarzyszeń, jak np. Zwiazek Pracy Obywatelskiej Kobiet, który wyłonił się 25 maja 1928 r. z byłego Demokratycznego Komitetu Wyborczego Kobiet Polskich, popierającego Bezpartyjny Blok Współpracy z Rządem Marszałka Piłsudskiego ${ }^{114}$. Zwiazkowi przewodniczyła Zofia Moraczewska, a funkcje wiceprzewodniczacych pełniły posłanki Maria Jaworska i Halina Jaroszewiczowa. W jego ramach działało siedem wydziałów: Wydział Uświadamiania Obywatelskiego, Wydział Oświaty, Wydział Kultury

\footnotetext{
${ }^{110}$ Ibidem, 4.

111 „Działalność naszych posłanek”, Kobieta Współczesna, nr 5, 1931, 18.

${ }^{112}$ Helena Ceysingerówna, „Szkoła patriotyzmu i służby obywatelskiej”, Kobieta Współczesna, nr 27, 1928, 2-3.

${ }^{113}$ Maria Ankiewiczowa, „Świat kobiecy w programach Polskiego Radia”, Kobieta Wspótczesna, nr 28, 1928, 19.

114 „Związek Pracy Obywatelskiej Kobiet”, Kobieta Współczesna, nr 32, 1928, 17-18.
} 
i Piękna, Wydział Opieki nad Kobieta, Wydział Opieki nad Matką i Dzieckiem, Wydział Wytwórczości Gospodarczej Kobiet, Wydział Finansowy i Prasowy. Monitorowano działania tej organizacji115, na bieżąco informowano o jej działalności ${ }^{116}$.

Śledzono powstawanie innych stowarzyszeń kobiecych, jak np. Zjednoczenie Kobiet Słowiańskich w Polsce, które zawiązało się 22 lutego 1931 r. w Krakowie $z$ Kołem w Warszawie, w celu zbliżenia narodów na niwie społecznej, kulturalnej i politycznej ${ }^{117}$.

Posłanka Eugenia Waśniewska tłumaczyła czytelniczkom pisma zasady finansowania państwa ${ }^{118}$. $Z$ uwagi na siłę i zasięg oddziaływania prasy na czytelników, $z$ czego redakcja zdawała sobie sprawę, zamieszczono sprawozdania $z$ Międzynarodowej Wystawy Prasy w Kolonii we wrześniu 1928 r. ${ }^{119}$ Eugenia Gulbinowa zachęcała do pracy społecznej pojmowanej jako służba narodowa i widziała konieczność współpracy międzypaństwowej w tym zakresie ${ }^{120}$. W publicystyce na łamach periodyku eksponowano rolę i znaczenie kobiety w życiu gospodarczym narodu $^{121}$.

Redaktorki pisma przeprowadzały wywiady $\mathrm{z}$ radnymi miejskimi, np. z Anną Brzezińska, radna m.st. Warszawy ${ }^{122}$.

Stanisława Goryńska $\mathrm{z}$ okazji 70 . urodzin przypadających w 1928 r. opisała sylwetkę szwedzkiej pisarki, laureatki Nagrody Nobla

\footnotetext{
115 „Zwiazek Pracy Obywatelskiej Kobiet”, Kobieta Współczesna, nr 41, 1928, 16-17; Helena Ceysingerówna, „Z działalności Związku Pracy Obywatelskiej Kobiet”, Kobieta Wspótczesna, nr 51, 1928, 18-19.

${ }^{116}$ Np.: „Dyskusja nad projektem Powszechnej Służby Obywatelskiej Kobiet”, Kobieta Współczesna, nr 5, 1931, 18; Helena Siemieńska, „Kurs dla referentek Wydziału Spraw Kobiecych Związku Pracy Obywatelskiej Kobiet”, Kobieta Współczesna, nr 8, 1931, 18; „Pamięci Marii Dulębianki”, Kobieta Wspótczesna, nr 12, 1931, 18.

${ }_{117}$ Anna Paradowska-Szelagowska, „Zjednoczenie Kobiet Słowiańskich w Polsce”, Kobieta Współczesna, nr 16, 1931, 19.

${ }^{118}$ Eugenia Waśniewska, „Ministerstwo Skarbu a zagadnienia przyszłości narodu”, Kobieta Współczesna, nr 39, 1928, 2.

${ }^{119}$ Helena Witkowska, „Kobieta a prasa. Wrażenia i uwagi z Międzynarodowej Wystawy Prasy w Kolonii", Kobieta Współczesna, nr 40, 1928, 5-7; Kobieta Współczesna, nr 41, 1928, 1.

${ }^{120}$ Eugenia Gulbinowa, „Międzynarodowa służba społeczna, Związek Pracy Obywatelskiej Kobiet”, Kobieta Wspótczesna, nr 42, 1928, 2-3.

${ }^{121}$ Irena Laskowska, „Rola i znaczenie kobiety w życiu gospodarczym narodu”, Kobieta Wspótczesna, nr 49, 1928, 2-4.

${ }^{122}$ I[rena] J[abłowska], „Rola kobiety w popieraniu przemysłu krajowego, Zwiazek Pracy Obywatelskiej Kobiet”, Kobieta Współczesna, nr 48, 1928, 3-4.
} 
z 1909 r., Selmy Lagerlöf, wielkiej zwolenniczki modelu współczesnej kobiety - wolnej i świadomej swych praw i obowiązków ${ }^{123}$.

Między wyborami przypominano kobiety, które walczyły o wolna Polskę oraz o równe prawa dla kobiet. Cecylia Walewska przywróciła pamięć o Marii Szelidze, jednej $z$ inicjatorek ruchu emancypacyjnego we Francji, która w 1889 r. zwołała w Paryżu Międzynarodowy Kongres Kobiecy, działajacej także aktywnie na gruncie amerykańskim ${ }^{124}$. Przyjrzano się działalności prekursorki feminizmu w Polsce - Narcyzy Żmichowskiej ${ }^{125}$. Powracano do ofiarnych działan organizacji kobiecych, przykładowo Związku Dobroczynności Patriotycznej z jej przewodnicząca Klementyna $z$ Tańskich Hoffmanową ${ }^{126}$.

Drukowano cykl artykułów pt. „O podstawy moralne współczesnego życia”, gdzie autorki dużo miejsca poświęciły etyce w polityce ${ }^{127}$.

\section{Zakończenie}

Jakościowa analiza zawartości wszystkich numerów „Kobiety Współczesnej" w latach 1928-1931, czyli w roku wyborów do sejmu i senatu (1928) oraz w okresie powyborczym, wyraźnie wykazała, że agitacja obywatelska kobiet prowadzona w piśmie przez same kobiety, wykształcone, świadome swej roli w nowej, wolnej ojczyźnie, zmierzała ku wyzwoleniu Polek spod supremacji mężczyzn i pracy u podstaw w rozwijaniu świadomości politycznej współobywatelek. Charakter zamieszczanych refleksji świadczy o tym, że redakcja pisma podjęła się pracy u podstaw, zdając sobie sprawę, że kobiety - jeśli mają współtworzyć nową Polskę same muszą wykonać tytaniczną pracę, by pokonać stereotypy kulturowe wykształcone w narodzie polskim przez wieki i wziąc stery w swoje ręce.

\footnotetext{
${ }^{123}$ Stanisława Goryńska, „W 70-letnią rocznicę urodzin Selmy Lagerlöf”, Kobieta Wspótczesna, nr 51, 1928, 11.

${ }^{124}$ Cecylia Walewska, „O równe prawa”, Kobieta Współczesna, nr 27, 1929, 4-5.

${ }^{125}$ R. Altenberg, „Dzieciństwo Narcyzy Żmichowskiej”, Kobieta Współczesna, nr 26, 1929, 12-13; cz. 2, Kobieta Współczesna, nr 27, 1929, 12-13.

${ }^{126}$ Maria Złotorzycka, „Warsztat pracy społecznej kobiet w 1831 roku”, Kobieta Współczesna, nr 6, 1931, 4-5.

${ }^{127}$ Np. Adela Minkowska, „Etyka a polityka”, Kobieta Współczesna, nr 8, 1931, 2.
} 


\section{Bibliografia}

\section{Źródła:}

Adamowiczowa, Stanisława. „Na marginesie nowej ustawy antyalkoholowej”, Kobieta Współczesna, nr 7, 1931, 5-6.

Adamowiczowa, Stanisława. „Ruch kobiecy w Szwajcarii”, Kobieta Współczesna, $\mathrm{nr}$ 51, 1928, 2-4.

Altenberg, R. „Dzieciństwo Narcyzy Żmichowskiej”, Kobieta Współczesna, nr 26, 1929, 12-13; cz. 2, Kobieta Współczesna, nr 27, 1929, 12-13.

„Angielki przygotowuja się do nowych wyborów parlamentarnych, Zwiazek Pracy Obywatelskiej Kobiet”, Kobieta Współczesna, nr 44, 1928, 17-18. Ankiewiczowa, Maria. „Moja wizyta u Gizeli Urban”, Kobieta Współczesna, nr 5, 1931, 14-15.

Ankiewiczowa, Maria. „Świat kobiecy w programach Polskiego Radia”, Kobieta Wspótczesna, nr 28, 1928, 19.

Bielańska, Karolina. „Córki Rzeczypospolitej”, Kobieta Wspótczesna, nr 10, 1928, 14-15.

Bielańska, Karolina. „Wyzwolona Penelopa”, Kobieta Wspótczesna, nr 52/53, 1928, 19-20.

Bogórska, Zofia. „Kobiety w parlamentach zagranicznych”, Kobieta Wspótczesna, nr 15, 1928, 2-4.

Buraczewska, Wanda. „Kobieta inżynier”, Kobieta Wspótczesna, nr 26, 1928, 2.

C-r. „Zjazd Rady Naczelnej Koła Kobiet”, Kobieta Współczesna, nr 16, 1928, 16-17.

Ceysingerówna, Helena. „Międzynarodowe kongresy społeczne w Paryżu. Wywiad z posłanką E. Waśniewska”, Kobieta Współczesna, nr 33, 1928, 2-3.

Ceysingerówna, Helena. „Polka na forum międzynarodowym”, Kobieta Współczesna, nr 32, 1928, 2-4.

Ceysingerówna, Helena., „Szkoła patriotyzmu i służby obywatelskiej”, Kobieta Wspótczesna, nr 27, 1928, 2-3.

Ceysingerówna, Helena. „Urzędniczki państwowe. Równouprawnienie”, Kobieta Współczesna, nr 10, 1928, 7-8. 
Ceysingerówna, Helena. „W poczuciu obowiazku obywatelskiego”, Kobieta Współczesna, nr 25, 1928, 4-5.

Ceysingerówna, Helena. „W przełomowym momencie”, Kobieta Wspótczesna, nr 3, 1928, 5.

Ceysingerówna, Helena. „Wśród prawodawców”, Kobieta Współczesna, nr 26, 1928, 3-4.

Ceysingerówna, Helena. „Z działalności Związku Pracy Obywatelskiej Kobiet”, Kobieta Współczesna, nr 51, 1928, 18-19.

Ceysingerówna, Helena. „Z rozważań przedwyborczych”, Kobieta Współczesna, $\mathrm{nr}$ 5, 1928, 4-5.

Ceysingerówna, Helena. „Zjazd delegatek Demokratycznego Komitetu Wyborczego Kobiet Polskich", Kobieta Wspótczesna, nr 15, 1928, 16-17.

"Ciche zwycięstwo feminizmu włoskiego”, Kobieta Współczesna, nr 3, 1931, 16.

„Druga kobieta sędzią dla nieletnich w Polsce”, Kobieta Współczesna, nr 8, 1931, 18.

„Dyskusja nad projektem Powszechnej Służby Obywatelskiej Kobiet”, Kobieta Współczesna, nr 5, 1931, 18.

„Działalność naszych posłanek”, Kobieta Współczesna, nr 5, 1931, 18.

Goryńska, Stanisława. „Emmeline Pankhurst. Wódz sufrażystek”, Kobieta Wspókczesna, nr 29, 1928, 5-6.

Goryńska, Stanisława. „W 70-letnią rocznicę urodzin Selmy Lagerlöf”, Kobieta Współczesna, nr 51, 1928, 11.

Goryńska, Stanisława. „Z wycieczki do Szwecji”, Kobieta Współczesna, nr 40, 1928, 18-19.

Grabińska, Wanda. „Kobieta w sądownictwie”, Kobieta Współczesna, nr 10, 1928, 5-6.

Grabińska, Wanda. „Projekt ustawy o sądach dla nieletnich. $Z$ cyklu "W obronie dziecka”", Kobieta Współczesna, nr 16, 1928, 2-4.

Grekowicz-Hausnerowa, Maria. „Ze Lwowa”, Kobieta Współczesna, nr 5, 1928, 16-17.

Gulbinowa, Eugenia. „Kobieta wobec swych praw i obowiąków chwili obecnej”, Kobieta Współczesna, nr 11, 1928, 2.

Gulbinowa, Eugenia. „Międzynarodowa służba społeczna, Związek Pracy Obywatelskiej Kobiet”, Kobieta Współczesna, nr 42, 1928, 2-3. 
Jabłowska, Irena. „Opieka nad dzieckiem robotnicy”, Kobieta Współczesna, nr 9, 1931, 16-17.

Jabłowska, Irena. „Rola kobiety w popieraniu przemysłu krajowego, Zwiazek Pracy Obywatelskiej Kobiet”, Kobieta Współczesna, nr 48, 1928, 3-4.

Jabłowska, Irena. „Sylwetki Polek w Ameryce”, Kobieta Współczesna, nr 41, 1928, 14-15.

Jabłowska, Irena. „Sylwetki Polek z Ameryki”, Kobieta Współczesna, nr 30, 1928, 11-12.

Jabłowska, Irena. „U nestorki dziennikarek polskich”, Kobieta Wspótczesna, nr 37, 1928, 5.

Jabłowska, Irena. „Z sądu dla nieletnich”, Kobieta Współczesna, nr 10, 1931, 5-6.

„Jeszcze jedna nominacja kobiety-sędziego”, Kobieta Współczesna, nr 14, 1931, 16.

„Jutrzenka ruchu feministycznego w Anglii”, Kobieta Współczesna, nr 49, 1928, 19.

Kneblewski, X. W. „Kobieta w Ameryce”, Kobieta Współczesna, nr 18, 1928, 13-15.

Kobieta Współczesna, nr 5, 1928, 18.

Kobieta Współczesna, nr 6, 1928, 17.

Kobieta Współczesna, nr 19, 1928, 2.

Kobieta Wspótczesna, nr 41, 1928, 1.

Kobieta Wspótczesna, nr 4, 1931, 23.

„Kobiety a polityka”, Kobieta Współczesna, nr 2, 1928, 2.

„Kobiety w parlamencie hiszpańskim, Zwiąek Pracy Obywatelskiej Kobiet”, Kobieta Współczesna, nr 42, 1928, 19.

„Komendantka policji kobiecej”, Kobieta Współczesna, nr 3, 1928, 19.

„Kongres Kobiet Hinduskich”, Kobieta Wspótczesna, nr 15, 1931, 18-19.

Krahelska, Halina. „Najbliższe zadania posłanek”, Kobieta Współczesna, nr 10, 1928, 6.

Krzyżanowska, Maria. „Pielgrzymka Związku Polek z Ameryki”, Kobieta Współczesna, nr 26, 1928, 18.

Krzyżanowska, Maria. „Rozmowa z pania Jadwiga Romerówna. Zwiazek Pracy Obywatelskiej Kobiet”, Kobieta Współczesna, nr 44, 1928, 4-5.

Kulczyńska, Teresa. „Pielęgniarstwo”, Kobieta Współczesna, nr 47, 1928, 2-3. 
Laskowska, Irena. „Kobieta - inżynier chemik”, Kobieta Wspótczesna, nr 34, 1928, 2-3.

Laskowska, Irena. „Rola i znaczenie kobiety w życiu gospodarczym narodu”, Kobieta Współczesna, nr 49, 1928, 2-4.

Lewartowicz, Stefania. „Suknia na wyrost”. Na marginesie ksiażki prof. Zygmunta Cybichowskiego", Kobieta Współczesna, nr 49, 1928, 8.

L.R. „W poszukiwaniu nowych form małżeństwa”, Kobieta Wspótczesna, nr 27, 1929, 6-7.

Męczkowska, Teodora. „Cieniom Jadwigi Sikorskiej”, Kobieta Współczesna, nr 2, 1928, 5-6.

Męczkowska, Teodora. „Do czego dążymy?”, Kobieta Wspótczesna, nr 39, 1931, 1-3.

Męczkowska, Teodora. „Kobiety - Sejm - Życie”, Kobieta Współczesna, nr 10, 1928, 2.

Minkowska, Adela. „Etyka a polityka”, Kobieta Wspótczesna, nr 8, 1931, 2. „Nowa kobieca organizacja polityczna”, Kobieta Współczesna, nr 6, 1928, 17. „Nowe stypendium międzynarodowe dla kobiet dla dopełnienia studiów we Francji”, Kobieta Wspótczesna, nr 50, 1928, 16.

„Nowy zastęp adwokatek”, Kobieta Współczesna, nr 27, 1929, 18.

"Odpowiedzi na ankietę «Kobiety Współczesnej»”, Kobieta Współczesna, nr 10, 1928, 9-13.

„Pamięci Marii Dulębianki”, Kobieta Wspótczesna, nr 12, 1931, 18.

Paradowska-Szelagowska, Anna. „Ruch kobiecy na Wschodzie”, Kobieta Wspótczesna, nr 8, 1931, 16.

Paradowska-Szelagowska, Anna. „Zagraniczna prasa kobieca”, Kobieta Wspótczesna, nr 16, 1931, 3-4.

Paradowska-Szelagowska, Anna. „Zjednoczenie Kobiet Słowiańskich w Polsce”, Kobieta Wspótczesna, nr 16, 1931, 19.

Pełczyńska, Wanda. „Po wyborach”, Kobieta Współczesna, nr 13, 1928, 3. „Praca nocna kobiet”, Kobieta Współczesna, nr 13, 1931, 18.

„Prace Czeskiej Rady Narodowej Kobiet”, Kobieta Współczesna, nr 12, 1928, 19.

„Przyp. Redakcji”, Kobieta Współczesna, nr 3, 1928, 5.

„Rezultaty wyborów do parlamentu austriackiego", Kobieta Współczesna, nr 7, 1931, 20. 
Rodziewicz, Maria. „Mili Goście, swojacy - witajcie...”, Kobieta Współczesna, nr 23, 1928, 2.

„Ruch kobiecy na Łotwie”, Kobieta Wspótczesna, nr 28, 1928, 14-15.

„Ruch polityczny wśród kobiet”, Kobieta Wspótczesna, nr 5, 1928, 16-17.

„Ruch przedwyborczy wśród kobiet w Wilnie”, Kobieta Współczesna, nr 7, 1928, 16.

Samotyhowa, Natalia. „Wartość współczynnika żeńskiego w pracy parlamentu”, Kobieta Współczesna, nr 10, 1928, 4-5.

„[Siedem] 7 kobiet w parlamencie Stanów Zjednoczonych”, Kobieta Wspótczesna, nr 9, 1931, 19.

Siemieńska, Helena. „Kurs dla referentek Wydziału Spraw Kobiecych Zwiąku Pracy Obywatelskiej Kobiet”, Kobieta Wspótczesna, nr 8, 1931, 18.

Siemieńska Helena. „W walce o byt”, Kobieta Wspókczesna, nr 11, 1931, 3-4. Siemieńska, Helena. „W walce o byt”, Kobieta Wspótczesna, nr 15, 1931, 3-4. „Służba Obywatelska”, Kobieta Współczesna, nr 26, 1928, 17-18.

S.N. „Maria Weryho-Radziwiłłowiczowa”, Kobieta Współczesna, nr 9, 1928, 7-8.

„Stowarzyszenie Kobiet z Wyższym Wykształceniem”, Kobieta Współczesna, nr 16, 1928, 16.

„Sukces posłanki Eugenii Waśniewskiej w Genewie”, Kobieta Współczesna, nr 26, 1928, 16.

Sz.S. „Z życia ś.p. Jadwigi Sikorskiej”, Kobieta Współczesna, nr 2, 1928, 5. Szmurłowa, Grażyna. „Zasady projektu prawa małżeńskiego”, Kobieta Wspótczesna, nr 15, 1931, 2-3.

Szybalska, Zofia. „Nauczycielstwo”, Kobieta Wspótczesna, nr 25, 1928, 2-3. Wacki, K. „Gość z Ameryki - Emilia Napieralska”, Kobieta Współczesna, nr 4, 1928, 14-15.

Walewska, Cecylia. „Ciekawy dokument kobiecy z końca XVIII w.”, Kobieta Wspótczesna, nr 19, 1928, 5-6.

Walewska, Cecylia. „O równe prawa”, Kobieta Współczesna, nr 27, 1929, 4-5.

Walewska, Cecylia. „Ryta Gnus”, Kobieta Współczesna, nr 16, 1928, 15-16.

Wasilewska, Wanda. „Ze wspomnień kurierki. Cz. 2, Zwiazek Pracy Obywatelskiej Kobiet”, Kobieta Współczesna, nr 47, 1928, 8-9; Cz. 3, Kobieta Współczesna, nr 48, 1928, 12; Cz. 4, Kobieta Współczesna, nr 49, 1928, 10. 
Waśniewska, Eugenia. „Kobiety w Sąach Pracy”, Kobieta Współczesna, nr 7, 1931, 19.

Waśniewska, Eugenia. „Ministerstwo Skarbu a zagadnienia przyszłości narodu", Kobieta Wspótczesna, nr 39, 1928, 2.

„Wezwanie”, Kobieta Współczesna, nr 23, 1928, 17.

Więckowska, Helena. „W sprawie równouprawnienia na uniwersytetach”, Kobieta Wspótczesna, nr 10, 1928, 8.

Wisłocka, Wanda. „Zawód lekarski”, Kobieta Współczesna, nr 40, 1928, 2-5.

Witkowska, Helena. „Kobieta a prasa. Wrażenia i uwagi z Międzynarodowej Wystawy Prasy w Kolonii”, Kobieta Współczesna, nr 40, 1928, 5-7.

Witkowska, Helena. „Na marginesie książki dr Zofii Daszyńskiej-Golińskiej”, Kobieta Wspótczesna, nr 18, 1928, 2.

Witkowska, Helena. „Wychowanie obywatelskie”, Kobieta Współczesna, nr 20, 1928, 28.

Witkowska, Helena. „Zawody społeczne”, Kobieta Współczesna, nr 24, 1928, 2-3.

Wojeńska, Czesława. „Józefina Butler (1828-1928)”, Kobieta Współczesna, nr 24, 1928, 19.

Woniczek, Helena. „Z niwy naukowej”, Kobieta Wspótczesna, nr 6, 1928, 2-4.

Z.B. „Sprawa kobieca w Afryce”, Kobieta Wspótczesna, nr 26, 1928, 19.

Z.B. „Z Belgii”, Kobieta Współczesna, nr 22, 1928, 18-19.

„Z działalności Klubu Politycznego Kobiet Postępowych”, Kobieta Współczesna, $\mathrm{nr}$ 8, 1928, 17.

„Z działalności kobiet górnośląskich”, Kobieta Współczesna, nr 11, 1928, 19.

„Z Klubu Kobiet Postępowych”, Kobieta Współczesna, nr 15, 1931, 16.

„Z krainy tulipanów”, Kobieta Wspótczesna, nr 50, 1928, 19.

Zandowa, Zofia. „Nowe prawo małżeńskie”, Kobieta Współczesna, nr 13, 1931, 2-3.

Zawirska, Jadwiga, „Różnice psychiczne pomiędzy kobietą i mężczyzną a wybór zawodu", Kobieta Współczesna, nr 39, 1928, 3-5.

Złotorzycka, Maria. „Warsztat pracy społecznej kobiet w 1831 roku”, Kobieta Wspótczesna, nr 6, 1931, 4-5.

„Zwiazek Pracy Obywatelskiej Kobiet”, Kobieta Współczesna, nr 32, 1928, 17-18.

„Zwiąek Pracy Obywatelskiej Kobiet”, Kobieta Wspótczesna, nr 41, 1928, 16-17. 


\section{Opracowania:}

Bauchrowicz-Tocka, Maria. „Zakonspirowane mężatki», czyli o ograniczeniach obyczajowych i prawnych wobec pracujących kobiet na łamach "Tygodnika Kobiety", w: Małgorzata Dajnowicz, Adam Miodowski (red.), Polityka i politycy $w$ prasie XX i XXI wieku. Polityka $w$ prasie kobiecej, (Białystok: Wydawnictwo Uniwersytetu w Białymstoku, 2019), 103-116. ISBN 978-83-7431-561-6.

Chwastyk-Kowalczyk, Jolanta. „Próby uobywatelnienia kobiet w okresie dwudziestolecia międzywojennego na łamach "Bluszczu»", w: Małgorzata Dajnowicz, Adam Miodowski (red.), Polityka i politycy w prasie XX i XXI wieku. Polityka w prasie kobiecej, (Białystok: Wydawnictwo Uniwersytetu w Białymstoku, 2019), 75-102. ISBN 978-83-7431-561-6.

Dawidowicz, Aneta. „Problematyka polityki i polityków na łamach "Głosu Kobiet", czasopisma dla kobiet wydawanego w latach 1908-1939", w: Malgorzata Dajnowicz, Adam Miodowski (red.), Polityka i politycy $w$ prasie XX i XXI wieku. Polityka $w$ prasie kobiecej, (Białystok: Wydawnictwo Uniwersytetu w Białymstoku, 2019), 57-71. ISBN 978-83-7431-561-6.

Dufrat, Joanna. „Polityka na łamach "Pracy Obywatelskiej” (1928-1939), organu prasowego sanacyjnego Zwiazku Pracy Obywatelskiej Kobiet”, w: Małgorzata Dajnowicz, Adam Miodowski (red.), Polityka i politycy $w$ prasie XX i XXI wieku. Polityka w prasie kobiecej, (Białystok: Wydawnictwo Uniwersytetu w Białymstoku, 2019), 117-129. ISBN 978-837431-561-6.

Gawin, Magda. „Planowanie rodziny - hasła i rzeczywistość”, w: Anna Żarnowska, Andrzej Szwarc (red.), Równe prawa i nierówne szanse: kobiety $w$ Polsce międzywojennej, (Warszawa : DiG, 2000). ISBN 83-7181-023-7.

Kałwa, Dobrochna. „Model kobiety aktywnej na tle sporów światopoglądowych. Ruch feministyczny w dwudziestoleciu międzywojennym", w: Anna Żarnowska, Andrzej Szwarc (red.), Równe prawa i nierówne szanse: kobiety $w$ Polsce międzywojennej, (Warszawa : DiG, 2000), 135-153. ISBN 83-7181-023-7.

Maj, Ewa. „Kobieta wobec polityki: strategie tożsamościowe w publicystyce tygodnika "Na Posterunku" (1917-1919)", w: Małgorzata Dajnowicz, Adam Miodowski (red.), Polityka i politycy w prasie XX i XXI wieku. Po- 
lityka $w$ prasie kobiecej, (Białystok: Wydawnictwo Uniwersytetu w Białymstoku, 2019), 43-56. ISBN 978-83-7431-561-6.

„Męczkowska Teodora”, oprac. Halina Więckowska, w: Polski Słownik Biograficzny, t. 20, (Wrocław-Warszawa-Kraków-Gdańsk : Wydawnictwo Polskiej Akademii Nauk, 1975), 503-504.

Polskie Kobiece Stowarzyszenia i Zwiazki Wspótpracy Międzynarodowej Kobiet, oprac. Jan Bełcikowski, (Warszawa : Towarzystwo Wydawnicze „Polska Zjednoczona”, 1939).

Wierzbicka, Maria. „Polskie Stowarzyszenie Kobiet z Wyższym Wykształceniem", w: Agnieszka Janiak-Jasińska, Katarzyna Sierakowska, Andrzej Szwarc (red.), Działaczki społeczne, feministki, obywatelki. Samoorganizowanie się kobiet na ziemiach polskich po 1918 roku (na tle porównawczym), t. 2, (Warszawa : B5, 2009), 153-175. ISBN 978-83-7543-101-8.

Zaleska, Zofia. Czasopisma kobiece $w$ Polsce. (Materiaty do historii czasopism). Rok 1818-1937, (Warszawa : Wyższa Szkoła Dziennikarska, 1938). 